\title{
THE CHANGES IN CHEMICAL AND PHYSICAL PROPERTIES OF FIBRIC PEAT FOLLOWING BURNING
}

\author{
B.H. Saharjo ${ }^{1}$ and A.D. Nurhayati2 \\ ${ }^{1}$ Forest Fire Laboratory, Faculty of Forestry, Bogor Agricultural University, Indonesia, \\ P O.BOX 168 Bogor, Phone: 62251421929, Fax: 62251621256, e-mail: sahario@indo.net.id \\ 2Alumni, Faculty of Forestry, Bogor Agricultural University, Indonesia, \\ PO. BOX 168 Bogor, Phone: 62251421929, Fax: 62251621256
}

\begin{abstract}
Fire is still used until today for land preparation because it is cheap, easy and relatively quick to be done, meanwhile the impact is still not much yet known especially for peat land. Due to that reason the research especially on peat quality following burning is highly important in order to understand the performance of it in the term of sustainability.

The research objective was to understand the performance of burned peat quality compared to the condition before burning at fibric peat especially in the land preparation area using fire belong to the shifting cultivator. The site was located in the Pelalawan district, Riau province, Indonesia, during the dry season in the year 2001. To reach the research objective 2 plots of each $400 \mathrm{~m}^{2}(20 \mathrm{~m} \times 20 \mathrm{~m})$ were established.

The results of the research shown that soon following burning, chemical properties of burned peat was increased significantly, while after one month part of them tended to decrease such as $P, K$, and base saturation. Three months after burning most of the chemical properties decreased while at six month a few of them was still increased such as $P$, Na and CEC. This research shown that the increasing of ash afterburning was a temporary effect and others negative impact is continued.
\end{abstract}

Key words: fire, peat burning, peat quality

\section{INTRODUCTION}

The immediate effeet of a forest fire is to convert vegetation to nutrient rich ash, which can nourish the regrowing of a new forest. However, due to the fires is too hot, the soil surface hardens, making it difficult for seeds to sprout, and causing the ash to be washed away by the first heavy rain (Wirawan, 1993). Intense burns and subsequent soil erosion result in the loss of other soil constituents that facilitate vegetation re-growth, such as organic matter, soil organisms that accelerate plant matter decomposition, and special fungi that assist key tree species to absorb nutrients. A comparison of soil erosion rates between burned and unburned forest in Kutai National Park showed that erosion had accelerated more than tenfold in the burned areas (Shimokawa, 1988). Soil erosion does not occur in the aftermath of peat swamp fires, but ash and other fire residues are washed away. The surface level of burned peat is lowered by combustion losses.

The effects of fire on the chemical and physical properties of forest soil vary from nil to profound depending on the type of soil, the moisture content of the soil, the intensity and duration of the fire and the time and intensity of post fire precipitation (Chandler et al., 1983). Soil properties may change in response to heat and increased exposure (Ralston and Hatchell, 1977) and burning apparently alters partitioning of nutrients between litter and soil mineral (Wells, 1971). The short-term effects of fire on nutrient availability depend on thermal effects of the fire, organic compounds, the rise of soil $\mathrm{pH}$, and microbial processing of organic matter (Binkley et al., 1993). The presence or absence of duff, humus and others unincorporated organic material in the forest floor and the amount of it consumed is key importance in appraising soil effects (Brown and Davis, 1973).

Each burning should be considered as different problem, and that no general conclusions should be drawn since soil conditions prevailing after a fire vary with the intensity of the fire, the nature of past material and the site quality (Brown, 1943).

\section{MATERIALS AND METHOD}

\section{Site and Time Period}

The research was done from August 2001 to July 2002 in the shifting cultivation area belong to the community of Pelalawan Village that is dominated by fibric peat that is known from soil map made by PT. Riau Andalan Pulp and Paper (PT. RAPP) which has land near the research site and soil analysis. The research site is located in Pelalawan subDistrict, Pelalawan District, Riau Province.

Vegetation analysis shown that the research site was dominated by shrubs and ferns, the vegetation found were Shorea macrophylla, Macaranga pruinosa, Ficus sundaica, Stenochlaena palustris, Parastemon uruphyllus, Baccaurea pendula, Nephorlepis flaccigera and Gleinchenia linearis.

Climate in Pelalawan District cannot be separated from Riau Province condition. Generally the site was tropical climate with annual rainfall range between 2500 and 3000 $\mathrm{mm}$ with daily temperature between $22{ }^{\circ} \mathrm{C}$ and $31{ }^{\circ} \mathrm{C}$. According to data made by Meteorological and Geophysical Agency, Ministry of Transportation, annual

Saharjo, B. H. and A, D. Nurhayati. 2003. The changes in chemical and physical propertics of peat following burning. J. Tanah Lingk., 5(1):1-6. 
rainfall in the period between January and December 2001 in the site was $3794.5 \mathrm{~mm}$ with 86 rainy days.

\section{Sampling Method}

Sampling was conducted through purposive sampling technique based on the plot design.

\section{Sampling Data}

To reach the objective, the research was conducted in the field and at laboratory scale. Two plots of $400 \mathrm{~m}^{2}(20 \mathrm{~m}$ $X 20 \mathrm{~m}$ ) each were established at fibric type of peat named fibric 1 and 2 .

Soil sampling, environmental condition measurement and fuel characterization were conducted before slashing and burning. Slashing was conducted where big log (diameter more than $10 \mathrm{~cm}$ ) send out from the plot. Slashed logs and branches were separated through the plot. During slashed period (drying process), fuel characterization was conducted at different time of measurement accompanied by monitoring of environmental condition such as temperature, relative humidity and wind speed. Following slashing was drying for a period of 4 weeks as it usually done by the community.

\section{Fire Behavior}

\section{Activities conducted before burning}

Three sub-plots of $2 \mathrm{~m}^{2}(2 \mathrm{~m} \times 1 \mathrm{~m})$ in each $400-\mathrm{m}^{2}$ plot were established in order to measure fuel characteristics such as fuel moisture, fuel bed depth, and fuel load.

Three samples each of 100-gram materials found in the sub-plots (litter, leaves, branches, and logs) were taken and used as samples for moisture content measurement. Samples were put in the oven and dried for $\mathbf{4 8}$ hours at $75^{\circ} \mathrm{C}$ (Clar and Chaten, 1954). Fuel moisture content was estimated through dry weight based measurement.

Fuel load was estimated through the amount of plants materials both living and dead in the sub-plots which were collected, separated and weighed.

Fuel bed depth was measured by the average height of the association of living and dead plant materials of various sizes and shapes in the subplots.

\section{Activities conducted during burning}

Flame temperature at $0 \mathrm{~cm}$ and $1 \mathrm{~cm}$ under the peat surface were measured using data logger. The temperature censors were placed in the subplot at two locations. Burning was conducted through circle method and allowing the fire to propagate naturally.

Rate of the spread of fire was measured by the average distance perpendicular to the moving flame front per minute, using a stopwatch and through a video camera recording.
It was very difficult to measure the average height of the flame directly at the time of burning. The flame height was calculated through video camera recording.

\section{Activities conducted following burning}

Soon following burning; heat penetration depth was measured by digging 5 sub-plots each of $400 \mathrm{~cm}^{2}$ and 30 cm depth.

Fuel left in the plot was measured by establishing 5 sub-plots $1 \mathrm{~m}^{2}$ in every plot. Those fuels left in the plot was weighted and checked.

Fire intensity was calculated using Byram's equation (Chandler et al., 1983), $\mathrm{FI}=273(\mathrm{~h})^{2.17}$, where $\mathrm{FI}$ is fire intensity $\left(\mathrm{kW} \mathrm{m}^{-1}\right)$ and $\mathrm{h}$ is flame height $(\mathrm{m})$.

\section{Soil Chemical Properties Changes}

\section{Activities conducted before and after burning}

Three random peat samples up to $1 \mathrm{~kg}$ with $10-\mathrm{cm}$ depth were taken before and immediately, 3 and 6 months following burning. Peat samples were collected in plastic containers, taken to the laboratory and analyzed. Soil chemical properties analyzed were $\mathrm{pH}\left(\mathrm{H}_{2} \mathrm{O}\right)$; $\mathrm{C}$-organic (Walkley and Black method); available phosphorus (Bray $\mathrm{I}$ method); and exchangeable cations; calcium (Ca), magnesium $(\mathrm{Mg})$, potassium $(\mathrm{K})$, sodium $(\mathrm{Na})$, and total bases (1 $\mathrm{M} \mathrm{NH}_{4} \mathrm{OAc}$ at $\mathrm{pH} 7.0$ ).

Three random peat samples at $0-20 \mathrm{~cm}$ depth were taken before and immediately, 3 and 6 months following burning for physical properties analysis. Peat samples were collected using a copper cylinder (diameter $10-\mathrm{cm}$ ) in order to allow the samples to retain their natural characteristics in laboratory analysis.

Peat physical properties analyzed were bulk density ( $\mathrm{g}$ $\left.\mathrm{c}^{-3}\right)$, porosity $(\%)$, moisture content $(\%)$, and permeability (\%).

These soil chemical and physical properties were analyzed at the Laboratory of Department of Soil Science, Faculty of Agriculture, Bogor Agricultural University, Indonesia.

\section{Data Analysis}

A completely randomized design of variance was used to test for differences among subplots, based on the following model (Steel and Torrie 1981):

Where,

$$
Y m n=\mu+T m+E m n
$$

$$
\begin{aligned}
\mathrm{Ymn}= & \text { fuel and fire behavior parameter at } \mathrm{m} \text { subplot } \\
& \text { in } \mathrm{n} \text { replication } \\
\mu & =\text { mean of the treatment population sampled } \\
\mathrm{Tm}= & \text { treatment (slashing, drying, burning) } \\
\mathrm{Emn}= & \text { random component }
\end{aligned}
$$

To detect significant difference of fuel and fire behavior parameters among subplots $(p \leq 0.05)$, the Duncan test was used (Steel and Torrie 1981). 


\section{RESULTS AND DISCUSSION}

\section{Results}

\section{Before burning}

Before burning temperature was vary from $36{ }^{\circ} \mathrm{C}$ in fibric 2 to $37^{\circ} \mathrm{C}$ in fibric 1 , relative humidity vary from $52 \%$ in fibric 2 to $53 \%$ in fibric 1 and wind speed vary from $0.67 \mathrm{~m} /$ minute in fibric 2 to $1.05 \mathrm{~m} /$ minute in fibric 1 (Table 1).

Table 1. Weather Condition and Fire Behavior during Burning

\begin{tabular}{lcc}
\multicolumn{1}{c}{ Parameter } & Fibric 1 & Fibric 2 \\
\hline Weather condition & & \\
Temperature $\left({ }^{\circ} \mathrm{C}\right)$ & 37 & 36 \\
Relative humidity & 53 & 52 \\
$(\%)$ & & 0.67 \\
Wind speed (m & 1.05 & \\
sec $^{-1}$ ) & & \\
Fire behavior & &
\end{tabular}

\begin{tabular}{|c|c|c|}
\hline Fuel load (ton ha ${ }^{-1}$ ) & $(62.67 \pm 12.59) \mathrm{a}$ & $61.56 \pm 13.16) \mathrm{a}$ \\
\hline - Litter & $(33.0 \pm 5.07)$ & $(28.50 \pm 3.50)$ \\
\hline - Branches & $(29.67 \pm 7.52)$ & $(33.0 \pm 9.66)$ \\
\hline $\begin{array}{l}\text { Fuel bed depth } \\
\text { (cm) }\end{array}$ & $(54.7 \pm 8.9) \mathrm{b}$ & $(42.3 \pm 7.8) \mathrm{a}$ \\
\hline \multicolumn{3}{|l|}{ Fuel moisture (\%) } \\
\hline - Leaves & $(8.63 \pm 1.10) a$ & $(9.19 \pm 4.59) \mathrm{a}$ \\
\hline - Branches & $(15.60 \pm 3.59) \mathrm{b}$ & $(12.85 \pm 4.85) \mathrm{a}$ \\
\hline - Peat surface & $(85.6 \pm 1.34) \mathrm{a}$ & $(84.75 \pm 0.78) \mathrm{a}$ \\
\hline Flame length (m) & $(4.12 \pm 1.53) \mathrm{a}$ & $(3.69 \pm 1.8) \mathrm{b}$ \\
\hline Fire int. $\left(\mathrm{kW} \mathrm{m}^{-1}\right)$ & $(6721.24 \pm 5018.34) b$ & $(5300.28 \pm 4117.48) a$ \\
\hline $\begin{array}{l}\text { R.of the } \\
\text { spr.(m/mnt) } \\
\text { Flame temp. }\left({ }^{\circ} \mathrm{C}\right)\end{array}$ & $(3.31 \pm 1.27) b$ & $(1.47 \pm 0.39) \mathrm{a}$ \\
\hline $\begin{array}{l}\text { - } 1 \mathrm{~cm} \text { below } \\
\text { ground }\end{array}$ & 75 & 90 \\
\hline $\begin{array}{l}\text { - Ground } \\
\text { Burned fuel (\%) }\end{array}$ & 875 & 900 \\
\hline - Litter & 95 & 85 \\
\hline - Branches & 75 & 55 \\
\hline - $\log$ & & 5 \\
\hline Slope (\%) & 0 & 0 \\
\hline Plot size (ha) & 0.04 & 0.04 \\
\hline Duration (mnt.) & 5.18 & 16.30 \\
\hline Burining time & $12.25 \mathrm{pm}$ & $13.30 \mathrm{pm}$. \\
\hline
\end{tabular}

Means are significantly different when standard errors are followed by different letters $(p \leq 0.05)$

Fuel load both in Fibric 1 and 2 vary from 61.5 ton/ha to $62.67 \mathrm{ton} / \mathrm{ha}$ (Table 1). This high fuel load caused high fire intensity that vary from $5300.28 \mathrm{~kW} \mathrm{~m}^{-1}$ (fibric 1) to $6721.24 \mathrm{~kW} / \mathrm{m}$ (fibric 2) due to high of flame height produced during burning that vary from $3.69 \mathrm{~m}$ (fibric 2) to $4.12 \mathrm{~m}$ (fibric 1). Since fibric materials have the lowest peat decomposition, it was water logged in its natural condition and causing high moisture content of peat. This shown by the evidence that burning mostly occurred in fuel beds depth, which vary from $97 \mathrm{~cm}$ to $106 \mathrm{~cm}$.

\section{Chemical and physical properties}

Before slashing (and burning), $\mathrm{pH}$ was varied from 3.3 to 3.7 ; organic-C was vary from 49.66 to $50.16 \%$; Nitrogen from 1.22 to $1.34 \%$; Phosphorus from 1.89 to $25.5 \mathrm{ppm}$; Calcium from 1.8 to 2.13 me $100 \mathrm{~g}^{-1}$; Magnesium from 1.61

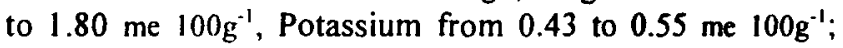
Sodium from 1.28 to 1.98 me $100 \mathrm{~g}^{-1}$; base saturation from 6.77 to $7.04 \%$ and CEC was vary from 77.33 to $95.04 \mathrm{me}$ $100 \mathrm{~g}^{-1}$ peat (Table 3).

Bulk density was varied from 0.11 in fibric 2 to $0.13 \mathrm{~g}$ $\mathrm{cm}^{-3}$ in fibric 1; porosity from 90.95 in fibric 1 to $91.90 \%$ in fibric 2; water holding capacity vary from 24.69 in fibric 2 to $32.01 \%$ in fibric 1 and permeability varied from 8.93 in fibric 1 to $20.39 \mathrm{~cm} \mathrm{hr}^{-1}$ in fibric 2 (Table 2).

\section{Following burning}

\section{Fire behavior}

Flame height was varied from $3.69 \mathrm{~m}$ in fibric 2 to 4.12 $\mathrm{m}$ in fibric 1, rate of the spread of fire vary from $1.47 \mathrm{~m}$ min. ${ }^{-1}$ in fibric 2 to $3.31 \mathrm{~m} \mathrm{~min}^{-1}$ in fibric 1, resulted flame temperature in the ground varied from $875^{\circ} \mathrm{C}$ in fibric 1 to $900{ }^{\circ} \mathrm{C}$ in fibric 2 and flame temperature $1 \mathrm{~cm}$ under the ground was varied from $75^{\circ} \mathrm{C}$ in fibric 1 to $90^{\circ} \mathrm{C}$ in fibric 2 . Fire intensity as one component to understand how fire behaves was varied from 5300 in fibric 2 to $6721 \mathrm{~kW} \mathrm{~m}^{-1}$ in fibric 1 (Table 1).

\section{Chemical and physical properties}

Chemical properties. Soon following burning in Fibric 1, pH, phosphorus, calcium, magnesium, potassium, sodium (fibric 2) and base saturation (fibric 1) increased significantly different (Table 3), while one month following burning $\mathrm{pH}$, phosphorus, potassium (fibric 1), and base saturation decreased, but nitrogen, calcium and CEC increased significantly different.

Three months after burning, nitrogen, phosphorus (fibric 1), magnesium (fibric 1), potassium, sodium, base saturation (fibric 1) and CEC decreased significantly different (Table 4). Six months following burning, nitrogen, phosphorus (fibric 1), calcium, magnesium, potassium, base saturation and CEC decreased significantly different (Table $3)$.

Physical properties. Soon following burning porosity (fibric 1), water holding capacity (fibric 2) and permeability decreased significantly different, while at three months after burning porosity (fibric 1) and permeability (fibric 2) decreased but permeability (fibric 1 ) increased significantly different (Table 2). Six months after burning bulk density (fibric 2) and water holding capacity (fibric 2) increased significantly different while permeability decreased significantly different (Table 2). 
Table 2. Physical Properties after Burning in Fibric 1 and 2

\begin{tabular}{lllll}
\hline \multicolumn{1}{c}{ Parameters } & \multicolumn{1}{c}{ BB } & SOAB & TAB & SAB \\
\hline Fibric I & & & & \\
Bulk density $\left(\mathrm{g} \mathrm{cm}^{-3}\right)$ & $(0.13 \pm 0.02) \mathrm{a}$ & $(0.14 \pm 0.05) \mathrm{a}$ & $(0.20 \pm 0.01) \mathrm{b}$ & $(0.20 \pm 0.01) \mathrm{b}$ \\
Porosity $(\%)$ & $(90.95 \pm 1.09) \mathrm{b}$ & $(89.56 \pm 3.33) \mathrm{b}$ & $(85.48 \pm 1.09) \mathrm{a}$ & $(92.62 \pm 0.42) \mathrm{b}$ \\
Water hold cap $(\%)$ & $(32.01 \pm 6.90) \mathrm{a}$ & $(25.44 \pm 7.92) \mathrm{a}$ & $(30.72 \pm 7.92) \mathrm{a}$ & $(27.38 \pm 0.94) \mathrm{b}$ \\
Permeability $\left(\mathrm{cm} \mathrm{hr}^{-1}\right)$ & $(8.93 \pm 4.59) \mathrm{d}$ & $(1.52 \pm 0.65) \mathrm{a}$ & $(6.28 \pm 5.95) \mathrm{c}$ & $(4.13 \pm 2.36) \mathrm{b}$ \\
& & & & \\
Fibric 2 & & & & $(0.15 \pm 0.04) \mathrm{b}$ \\
Bulk density $\left(\mathrm{g} \mathrm{cm}^{-3}\right)$ & $(0.11 \pm 0.02) \mathrm{a}$ & $(0.11 \pm 0.02) \mathrm{a}$ & $(89.52 \pm 2.70) \mathrm{a}$ & $(90.24 \pm 0.82) \mathrm{a}$ \\
Porosity $(\%)$ & $(91.90 \pm 1.09) \mathrm{a}$ & $(91.54 \pm 1.33) \mathrm{a}$ & $(23.08 \pm 0.45) \mathrm{a}$ & $(30.99 \pm 1.20) \mathrm{b}$ \\
Water hold. cap. $(\%)$ & $(24.69 \pm 1.51) \mathrm{a}$ & $(29.09 \pm 4.14) \mathrm{b}$ & $(0.88 \pm 0.83) \mathrm{a}$ \\
Permeability $\left(\mathrm{cm} \mathrm{hr}^{-1}\right)$ & $(20.39 \pm 4.32) \mathrm{d}$ & $(8.44 \pm 3.60) \mathrm{c}$ & $(3.59 \pm 2.69) \mathrm{b}$ & \\
\hline
\end{tabular}

Means are significantly different when standard errors are followed by different letters ( $p \leq 0.05)$

$\mathrm{BB}=$ Before burning, $\mathrm{SOAB}=$ Soon after burning; $\mathrm{TAB}=$ three month after burning; $\mathrm{SAB}=$ Six month after burning

Table 3. Chemical Properties Following Burning in Fibric 1 and 2

\begin{tabular}{|c|c|c|c|c|c|}
\hline Parameters & $\mathrm{BB}^{*}$ & SOAB & $\mathrm{OAB}$ & TAB & $\mathrm{SAB}$ \\
\hline \multicolumn{6}{|l|}{ Fibric I } \\
\hline $\mathrm{pH}$ & $3.3-3.7$ & $4.2-4.5$ & $3.3-3.7$ & $3.4-3.7$ & $3.6-3.7$ \\
\hline Org-C (\%) & $(50.16 \pm 3.14) \mathrm{a}$ & $(51.73 \pm 0.32) \mathrm{a}$ & $(51.17 \pm 1.60) \mathrm{a}$ & $(53.09 \pm 0.49) \mathrm{a}$ & $(48.99 \pm 3.60)$ \\
\hline$N(\%)$ & $(1.34 \pm 0.18)$ & $(1.43 \pm 0.07) c$ & $(1.68 \pm 0.36) d$ & $(0.32 \pm 0.09) \mathrm{b}$ & $(0.14 \pm 0.01) \mathrm{a}$ \\
\hline$P(p p m)$ & $(25.5 \pm 12.44) \mathrm{d}$ & $(43.73 \pm 2.06) \mathrm{e}$ & $(21.97 \pm 8.2) c$ & $(3.5 \pm 0.71) \mathrm{a}$ & $(6.6 \pm 1.4) b$ \\
\hline $\mathrm{Ca}\left(\mathrm{me} 100 \mathrm{~g}^{-1}\right)$ & $(2.13 \pm 1.42) c$ & $(4.81 \pm 1.22) \mathrm{d}$ & $(8.35 \pm 2.67) \mathrm{e}$ & $(1.19 \pm 0.33) b$ & $(0.93 \pm 0.04) \mathrm{a}$ \\
\hline $\mathrm{Mg}\left(\mathrm{me} 100 \mathrm{~g}^{-1}\right)$ & $(1.80 \pm 0.83) b$ & $(5.62 \pm 2.41) \mathrm{c}$ & $(5.08 \pm 1.21) c$ & $(0.59 \pm 0.18) \mathrm{a}$ & $(0.68 \pm 0.31) a$ \\
\hline$K\left(\right.$ me $\left.100 \mathrm{~g}^{-1}\right)$ & $(0.55 \pm 0.43) \mathrm{b}$ & $(3.6 \mathrm{l} \pm 2.03) \mathrm{d}$ & $(1.80 \pm 0.73) \mathrm{c}$ & $(0.23 \pm 0.05) a$ & $(0.24 \pm 0.09) \mathrm{a}$ \\
\hline $\mathrm{Na}\left(\mathrm{me} 100 \mathrm{~g}^{-1}\right)$ & $(1.98 \pm 1.44) \mathrm{c}$ & $(2.14 \pm 0.61) \mathrm{e}$ & $(1.68 \pm 0.19) b$ & $(0.32 \pm 0.03) \mathrm{a}$ & $(0.40 \pm 0.14) \mathrm{a}$ \\
\hline Base sat. (\%) & $(7.04 \pm 3.68) \mathrm{b}$ & $(17.78 \pm 7.82) \mathrm{d}$ & $(9.42 \pm 3.93) c$ & $(5.92 \pm 1.65) \mathrm{a}$ & $(5.58 \pm 0.11) \mathrm{a}$ \\
\hline $\mathrm{CEC}\left(\mathrm{me} 100 \mathrm{~g}^{-1}\right)$ & $(95.04 \pm 34.72) b$ & $(94.23 \pm 13.66) \mathrm{b}$ & $(150.8 \pm 26.87) d$ & $(41.12 \pm 10.45) \mathrm{a}$ & $(39.04 \pm 5.69) \mathrm{a}$ \\
\hline \multicolumn{6}{|l|}{ Fibric 2} \\
\hline $\mathrm{pH}$ & $3.5-3.6$ & $4.0-4.3$ & $3.5-3.7$ & $3.6-3.7$ & $3.6-3.9$ \\
\hline Org-C (\%) & $(49.66 \pm 5.62) \mathrm{a}$ & $(51.93 \pm 2.09) \mathrm{a}$ & $(50.86 \pm 1.40) \mathrm{a}$ & $(52.05 \pm 0.38) \mathrm{a}$ & $(52.63 \pm 0.11) \mathrm{a}$ \\
\hline$N(\%)$ & $(1.22 \pm 0.26) \mathrm{c}$ & $(1.09 \pm 0.27) \mathrm{c}$ & $(1.2 \pm 0.40) c$ & $(0.3 \pm 0.04) b$ & $(0.15 \pm 0.01) \mathrm{a}$ \\
\hline$P(\mathrm{ppm})$ & $(1.89 \pm 5.84) \mathrm{a}$ & $(33.07 \pm 11.21) \mathrm{e}$ & $(10.8 \pm 2.2) d$ & $(5.4 \pm 2.9) \mathrm{c}$ & $(4.47 \pm 0.64) b$ \\
\hline $\mathrm{Ca}\left(\mathrm{me} 100 \mathrm{~g}^{-1}\right)$ & $(1.8 \pm 0.83) c$ & $(4.87 \pm 2.87) d$ & $(7.67 \pm 1.40) \mathrm{e}$ & $(1.1 \pm 0.35) \mathrm{b}$ & $(0.93 \pm 0.04) \mathrm{a}$ \\
\hline $\mathrm{Mg}\left(\mathrm{me} 100 \mathrm{~g}^{-1}\right)$ & $(1.61 \pm 0.58) b$ & $(3.26 \pm 0.16) c$ & $(4.37 \pm 0.78) d$ & $(0.76 \pm 0.14) a$ & $(0.59 \pm 0.11) \mathrm{a}$ \\
\hline $\mathrm{K}\left(\mathrm{me} 100 \mathrm{~g}^{-1}\right)$ & $(0.43 \pm 0.33) b$ & $(1.81 \pm 0.61) \mathrm{d}$ & $(1.10 \pm 0.87) c$ & $(0.22 \pm 0.006) a$ & $(0.18 \pm 0.03) a$ \\
\hline $\mathrm{Na}\left(\mathrm{me} 100 \mathrm{~g}^{-1}\right)$ & $(1.28 \pm 0.46) b$ & $(1.48 \pm 0.56) b$ & $(1.91 \pm 0.08) \mathrm{c}$ & $(0.33 \pm 0.03) \mathrm{a}$ & $(0.36 \pm 0.05) a$ \\
\hline Base sat (\%) & $(6.77 \pm 1.56) \mathrm{b}$ & $(14.30 \pm 7.39) \mathrm{d}$ & $(14.62 \pm 0.29) \mathrm{d}$ & $(6.82 \pm 0.43) c$ & $(4.83 \pm 0.73) \mathrm{a}$ \\
\hline CEC (me $\left.100 \mathrm{~g}^{-1}\right)$ & $(77.33 \pm 8.11) \mathrm{c}$ & $(89.47 \pm 29.80) \mathrm{d}$ & $(93.61 \pm 7.38) \mathrm{e}$ & $(35.12 \pm 4.57) \mathrm{a}$ & $(42.92+3.04) \mathrm{b}$ \\
\hline
\end{tabular}

Means are significantly different when standard errors are followed by different letters ( $\mathrm{p} \leq 0.05)$

$\mathrm{BB}=$ Before burming. $\mathrm{SOAB}=$ Soon after buming; $\mathrm{OAB}=$ One month after burning; $\mathrm{TAB}=$ three month after burning; $\mathrm{SAB}=$ Six month after buming

\section{Discussion}

\section{Fire behavior}

High flame temperature resulted during burning that varied from $875^{\circ} \mathrm{C}$ to $900{ }^{\circ} \mathrm{C}$ at peat surface actually due to high fuel load available in the site that varied from 61.56 to 62.67 ton $\mathrm{ha}^{-1}$. This fuel load consist of litter varied from 28.5 to 33 ton $\mathrm{ha}^{-1}$ and branches from 29.67 to 33 ton/ha when burned will produce also high potency of ash and charcoal left in peat surface which will affect the quality of peat burned both chemical and physical properties.

No peat burned found at significant depth following burning actually was an indicator of high moisture content of peat at surface level, even though high fire intensity resulted during burning that varied from 5300.28 to $6721.24 \mathrm{~kW} \mathrm{~m}^{-1}$, which has direct effect of burning the materials both dead and live found on the peat surface. Fire intensity (Brown and Davis, 1973) is directly proportional to the amount of fuel available for combustion at any given rate of the spread of fire front and higher heat transfer 
causes the adjacent fuels to be heated and burned, thereby releasing more heat and propagating fire (Johnson, 1992). It seems that due to flame temperature $1 \mathrm{~cm}$ below peat surface that varied from 75 to $90{ }^{\circ} \mathrm{C}$ accompanied by rate of spread of fire that vary from 1.47 to $3.31 \mathrm{~m} \mathrm{~min}^{-1}$ give an implication that physical properties of burned peat less affected than chemical properties. Heat radiated downward in the soil is the driving mechanism for increasing soil temperatures in the soil. These temperature increase initiate a wide range of response in the soil physical, chemical and biological properties (DeBano et al., 1998).

\section{Chemical and Physical Properties}

\section{Chemical properties}

The results of research shown that soon following burning most of nutrients and $\mathrm{pH}$ increased significantly different except nitrogen and organic-C. This change was due to ash produced following burning, which contains high level of mineral. The short-term effects of fire on nutrient availability depend on the thermal effects of the fire on organic compounds, on the rise in soil $\mathrm{pH}$, and on microbial processing of organic matter (Binkley et al., 1993). The increasing of those nutrients soon following burning was temporary effects because one month (except $\mathrm{Ca}$ and $\mathrm{Mg}$ ), three and six months after burning it had been found that most of the chemical properties were decreased significantly. The decrease of most of nutrients both at three and six months after burning was believed due to nutrients release in the floor through ash produced was leached by surface run-off after precipitation that occurred a couple weeks after burning. Decreasing of $\mathrm{Ca}, \mathrm{Mg}, \mathrm{Na}$, and $\mathrm{K}$ after burning may be caused by leaching and run off (Toky and Ramakhrisnan, 1981; Saharjo and Makhrawie, 1998) and surface run-off and sediments in the run off can carry the elemnts in the ash and soil down stream (DeBano and Conrad, 1976). Those burned peat could not return back to the condition before burning (Table 1) because peat has irreversible characteristics so that burned peat was leached due to surface run off.

\section{Physical properties}

Disturbed peat due to fire will affect the physical properties. The magnitude of the change depends largely on the severity of fire, forest floor consumed, heating of the soil, proportion of area burned and lengths of fire intervals (Wells et al., 1979). Results of the researches show that soon following burning only water holding capacity (fibric 2) increased while others decrease significantly. Three months after burning, bulk density, water holding capacity, and permeability (fibric 2) and porosity (fibric 1) and six months after burning water holding capacity (fibric 2 ) and porosity (fibrioc 1 ) tended to increase significantly while other parameters tended to decrease or unchanged. The effect of fire on the chemical and physical properties of forest soil will vary significantly depending on the type of soil, the moisture content of the soil, the intensity and duration of fire, and the timing and intensity of post fire precipitation (Chandler et al., 1983). Soil properties may change in response to heat and increased exposure (Ralston and Hatchell, 1977). The decrease of permeability in three (fibric 2) and six months (fibric 1 and 2) after burning maybe due to no longer protection from impact action of raindrops and soil material becomes dispersed and compacted and finally will decrease soil permeability (Fuller et al., 1955). In addition of destroying litter layer, heat also killed insect and other microorganism channeled to the soil resulted in reduction of soil porosity (Kittredge, 1938) as it can be found in burned site.

\section{CONCLUSION}

High fire intensity accompanied by high flame temperature resulted during burning in fibric peat; give consequences both to chemical and physical properties of burned peat after burning. The effect become important to chemical properties as it had been found that no peat burned, even though there was an increasing of temperature $1 \mathrm{~cm}$ below the peat surface due to heat penetration.

Soon following burning it had been found that most of the chemical properties increased, at one and three months it was gradually tend to decrease and at six months except phosphorus in fibric 2 most of it was decrease significantly different compared to the condition before burning. The condition was different compared to the physical properties, where soon following burning it had been found that most of the soil physical properties decreased except water holding capacity in fibric 2 , at three months only bulk density increased while at six months bulk density (fibric 2) and water holding capacity (fibric 2 ) increased significantly different compared to the condition before burning. This fact shows that following burning the increasing of soil chemical properties was only temporary effects while negative impact is continued.

\section{ACKNOWLEDGMENT}

Authors thank to PT. Riau Andalan Pulp and Paper (PT. RAPP), PO Box 1080, Pekanbaru, Riau 28000 , Indonesia, which had given chance to have the research collaboration and funding assistance.

\section{REFERENCES}

Binkley, D., P. Becker-Heidman., J.S. Park., P.J. Crutzen., P. Frost., A.M. Gill., A. Granstrom., F. Mack., J.C. Menaut., R.W. Wein and B.D. Wilager. 1993. Impacts of fires on ecosystem. In: P.J. Crutzen and J.G. Goldammer (eds.). Fire in the Environment. The Ecological, Atmospheric and Climatic Importance of Vegetation Fires. John Wiley and Sons, New York.

Brown, A.A. and K.P. Davis. 1973. Forest Fire: Control and Use. $2^{\text {nd }}$ ed.. McGraw-Hill Book Company, New York. $65 \dot{8}$ pp.

Brown, I.C. 1943. A rapid method of determining exchangeable hydrogen and total exchangeable bases of soils. Soil Science. 56: $353-357$. 
Chandler. C.. P. Cheney, P. Thomas. L. Trabaud, and D. Williams. 1983. Fire in Forestry, Vol.1. Forest Fire Behavior and Effects. John Wiley and Sons, Inc. New York. 450.pp.

Clar, C.R and L.R. Chatten. (1954) Principles of Forest Fire Management. Department of Natural Resources Division of Forestry. California. $200 \mathrm{pp}$.

Debano, L.F., and C.E. Conrad. 1976. Nutrients lost in debris and run off water from a burned chapparal watershed. Federal Inter-Agency Sedimentation Conf. Proceeding, 3: 13-27.

Debano, L.. D.G. Neary and P.F. Ffolliott. 1998. Fire's Effects on Ecosystems. John Wiley and Sons, Inc. $319 \mathrm{pp}$.

Fuiler, W.H.S., S. Shannon, P.S. Burgess. 1955. Effect of burning on certain forest soils of Northern Arizona. Forest Science, 1(1): 44-50.

Jonson. E.A. 1992. Fire and Vegetation Dynamic. Cambridge Univ. Press. $127 \mathrm{pp}$.

Kittredge. J. 1938. Comparative infiltration in the forest and open. J. of Forestry, 36: 1156-1157.

Ralston. C. W and G.E. Hatchell. 1971. Effects of prescribed burning on physical properties of soil. In Prescribed Burning Symposium, USDA For. Serv. Southeastern For. Exp. Sta. p: 68-84.
Saharjo, B.H. and Makhrawie. 1998. The changes in soil chemical properties after fire in four-year-old Acacia mangium and Eucalyptus urophylla plantations. Tropical Ecology, 39(1): 97-102.

Shimokawa, E. 1988. Effects of fire of tropical forest on soil erosion. In $\mathrm{H}$. Tagawa and N. Wirawan. (eds.). A Research on the Process of Earlier Recovery of Tropical Rain Forest after a Large Scale Fire in Kalimantan Timur, Indonesia. Occasional Paper No.14, Research Center for the South Pacific, Kagoshima University. p. 1-2.

Steel, R.G. and J.H. Torrie. 1981. Principles and Procedures of Statistics: A Biometrical Approach. $2^{\text {nd }}$ ed.. McGraw-Hill. lnc. New York. 633 pp.

Toky, O.P. and P. Ramakhrisnan. 1981. Run-off and infiltration losses related to shifting agriculture (jhum) in Northeastern India. Environmental Conservation, 8:313-321.

Wirawan, N. 1993. The hazard of fire. In $\mathrm{H}$. Brookfield and $\mathrm{Y}$. Byron (eds.). Southeast Asias Environmental Future: The Search for Sustainability. United Nations University Press/Oxford University Press. pp. 242-260.

Wells, C.G. 1971. Effects of prescribed burning on physical properties of soil. In Prescribed Burning Symposium, USDA For. Serv. Southeastern For. Exp. Sta. p: 86-97. 